\title{
De grenzen van koloniale symbolische macht. Etnicisering en racialisering in Rwanda 1890-1960
}

\author{
Petra Veruust \\ Promotoren: Eric Vanhaute, Baz Lecocq \\ Vakgroep Geschiedenis, Universiteit Gent
}

Openbare verdediging: 8 september 2010

De eerste Europeanen die voet zetten in Rwanda waren gefascineerd door de plaatselijke bevolking en meer bepaald door de driedeling van deze bevolking in wat ze volksstammen, maar ook etnische groepen, rassen, enzovoort noemden. De manier waarop ze hen fotografeerden en beschreven was een manifestatie van koloniale symbolische macht in het vormgeven van etniciteit en ras. Wanneer symbolische macht met Pierre Bourdieu gedefinieerd wordt als de macht om de realiteit vorm te geven door middel van taal en visuele uitingen, kan de zogenaamde Hamitische hypothese beschouwd worden als de belangrijkste manifestatie van koloniale symbolische macht.

De Hamitische hypothese ging ervan uit dat alles wat cultureel waardevol was in Afrika daar gekomen was dankzij de zogenaamde Hamieten, een tak van het Kaukasische, blanke of Europese ras. Deze superieure Hamieten werden verondersteld vanuit het noordoosten inheemse Afrikaanse landbouwgemeenschappen te hebben onderworpen. In Rwanda werden 'de Tutsi' gelijkgesteld met Hamieten die 'de Hutu' hadden onderworpen. Het is deze Hamitische hypothese die tot in 1994 ten tijde van de genocide gebruikt werd als ideologisch wapen. De vermoorde Tutsi lichamen werden via de rivieren van het land zogezegd teruggestuurd naar Ethiopië, hun vermeende land van herkomst. Alleen al omwille van dit misdadig gebruik van de Hamitische hypothese die door koloniale actoren geïntroduceerd werd en niet op historische feiten gebaseerd is - kan en mag de koloniale erfenis niet getrivialiseerd worden.

Maar het feit dat de introductie van de Hamitische hypothese desastreuse gevolgen heeft gehad, betekent nog niet dat koloniale actoren het monopolie hadden over de uitoefening van symbolische macht: dit zou hen tot meer eer strekken dan ze verdienen. Daarom onderzoekt dit proefschrift de limieten of de grenzen van koloniale symbolische macht. Een vollediger begrip van etniciteit en ras in de Rwandese geschiedenis veronderstelt dat de symbolische macht van koloniale structuren en actoren niet overschat wordt ten koste van hun interactie met reeds bestaande lokale structuren en de agency van de zogenaamde gekoloniseerden.

De lokale actoren die aan bod komen in dit onderzoek bestaan uit elites, sociale klimmers of zogenaamde parvenus, een meerderheid van boeren en een minderheid van paria's. De belangrijkste koloniale actoren zijn reizigers, missionarissen, ambtenaren en een aantal geleerden. Hoewel ook aandacht wordt besteed aan de onmiddellijke prekoloniale periode, is het eigenlijke tijdskader beperkt tot de koloniale periode. Die 
begint met de met een aantal ontdekkingsreizen in de jaren I89o van voornamelijk Duitsers, die het zogenaamde Nyiginya koninkrijk aantroffen, een gecentraliseerd en uitbreidend koninkrijk. Het Duitse koloniale bewind in wat vandaag Rwanda is, begon officieel in 1898 als deel van 'Ruanda-Urundi', dat wil zeggen het huidige Rwanda en Burundi samen, en eindigde tijdens de Eerste Wereldoorlog. Daarna volgde het Belgische bewind onder toezicht van de Volkenbond tot aan de onafhankelijkheid in I962. Ruimtelijk wordt de regio behandeld die min of meer samenvalt met de huidige Rwandese staatsgrenzen. Rwanda bestond enerzijds uit een centrale regio (Nduga), waar de dynastieke macht het meest geconcentreerd was en anderzijds uit perifere regio's, waar deze staatsmacht in de vroeg koloniale periode nog heel oppervlakkig was.

De concepten etniciteit en ras worden zoals vandaag gebruikelijk in de sociale wetenschappen beschouwd als sociaal geconstrueerde groepsidentiteiten, waarvan de inhoud sterk fluctueert naargelang de historische omstandigheden. Om te benadrukken dat etniciteit en ras geen onveranderlijke essenties zijn, maar veranderlijke constructies doorheen tijd en ruimte, spreekt men vandaag over processen van etnicisering en racialisering, een terminologie die dit proefschrift graag heeft overgenomen. Ook andere identiteiten die aan bod komen, zoals klasse en gender, worden opgevat als veranderlijke constructies die respectievelijk draaien rond socio-economische verschillen en mannelijke en vrouwelijke identiteiten.

In de bestaande historiografie over Rwanda impliceert 'etnicisering' dat de politieke en sociale relevantie van etniciteit toenam onder het koloniale bewind. Waar het proces van etnicisering tot nog toe voornamelijk belicht is als een 'succes verhaal', belicht dit proefschrift de keerzijde, daar waar het proces gefaald is of tenminste potentieel had om te falen. Onder 'racialisering' verstaat men in de historiografie dat de etnicisering gepaard ging met een raciale ideologie. Maar - en hier wringt het schoentje - terwijl het begin van de etnicisering gesitueerd wordt in de prekoloniale periode, wordt het begin van de racialisering later gesitueerd, meer bepaald ten tijde van de komst van de eerste Europeanen. Ras werd tot nog toe in de Rwandese context voornamelijk beschouwd als een nieuw, door de Europese kolonisatoren geïmporteerd idee. Bovendien werd het concept ras in tegenstelling tot het concept etniciteit tot nog toe veeleer beschouwd als een louter gegeven dan als een historisch bepaald gegeven met een fluctuerende inhoud. Met andere woorden en in de terminologie van Frederik Cooper en Rogers Brubaker, ras werd tot nog toe weliswaar veelvuldig erkend als een categorie van de praktijk, maar veel minder als een categorie van analyse.

De hypothese die vooropgesteld werd in dit onderzoek luidt dat koloniale symbolische macht beperkt was omwille van twee redenen: ten eerste was de raciale ideologie waarmee het proces van etnicisering in Rwanda gepaard ging niet volledig nieuw. Het bouwde voort op reeds bestaande elementen die een proces van inculturatie mogelijk maakten. Het begrip inculturatie werd geleend van Frank Dikötter, die benadrukt dat inculturatie of actieve toe-eigening meer omvat dan enkel een acculturatie of assimilatie, wat een passievere rol voor de 'ontvangende' cultuur veronderstelt. Het tweede aspect van de hypothese houdt in dat de relevantie van etniciteit en ras in het koloniale beleid en in 
koloniale politiek uiteraard hoog was, maar niet altijd overheersend vergeleken met de relevantie van andere identiteiten.

Omwille van hun sociaal geconstrueerde aard kunnen etniciteit en processen van etnicisering onderzocht worden in hun relatie tot veranderende machtsverhoudingen. Volgens John Comaroff moet etniciteit bestudeerd worden als een variabele die afhangt van historische constellaties van materiële, politieke en symbolische macht. In dit proefschrift wordt etniciteit gelinkt aan deze drie door Comaroff gesuggereerde vormen van macht. De politieke machtsverhoudingen hebben vooral te maken met het staatsvormingsproces en de materiële machtsverhoudingen met de introductie van een nieuw klassenbewustzijn dat gebaseerd was op een op Europese lijst geschoeide repressie, cultuur, onderwijs en tewerkstelling. De symbolische machtsverhoudingen die centraal staan in dit proefschrift zijn vooral gekenmerkt door de verschuiving van een op klasse naar een op ras gebaseerde ideologie van etniciteit.

De bronnen waarop dit onderzoek gebaseerd is, werden geproduceerd tijdens de koloniale periode door voornamelijk Europese reizigers, missionarissen, ambtenaren en wetenschappers. Omdat het de bedoeling was om de eventuele continuitteit tussen de prekoloniale en koloniale periode te achterhalen, werd het zwaartepunt van het bronnenonderzoek op de vroeg koloniale periode gelegd. Het ontdekken van de opvattingen van Rwandese actoren gebeurde op basis van een aantal bronnen, waarbij vooral de geschriften van de Witte Pater Peter Schumacher een belangrijke rol hebben gespeeld. 